\title{
Five Times Monthly
}

National Cancer Institute

\section{Source}

National Cancer Institute. Five Times Monthly. NCI Thesaurus. Code C98850.

Five times per month. 